\title{
Thermodynamics of basal freeze-on: predicting basal and subglacial signatures of stopped ice streams and interstream ridges
}

\author{
Poul CHRISTOFFERSEN, ${ }^{1}$ SlaweK TULACZYK ${ }^{2}$ \\ ${ }^{1}$ Department of Civil Engineering, Technical University of Denmark, Building 204, DK-2800 Lyngby, Denmark \\ E-mail: pc@byg.dtu.dk \\ ${ }^{2}$ Department of Earth Sciences, University of California Santa Cruz, 1156 High Street, Santa Cruz, CA 95064, U.S.A.
}

\begin{abstract}
We have constructed a numerical model that simulates the response of subglacial sediments to basal freeze-on. The model is set up to emulate the basal zone of drilling sites in the Ross Sea sector of the West Antarctic ice sheet. We treat basal freeze-on at an ice-sediment interface as a thermodynamic process that couples the flow of water, heat and solutes in unfrozen subglacial sediments underlying a freezing ice base. The coupling of these flows occurs through the Clapeyron equation, which specifies the dependence of the basal freezing/melting temperature on ice pressure, water pressure, solute concentration and surface tension effects. Thermally driven water flow is induced when an ice base becomes supercooled below the pressure-melting point because ice--water surface tension inhibits ice growth in small pore spaces of fine-grained subglacial sediments. Our model results show that basal freeze-on is capable of inducing considerable changes in the basal zone of both ice streams and interstream ridges. These changes are associated with specific signatures that compare with borehole observations and geophysical surveys. Water-pressure levels are reduced, and thick layers of debris-laden basal ice develop. These basal ice layers and underlying sediments contain a distinct isotopic signal. The predicted stable-isotope ratios reflect Rayleigh-type isotopic fractionation whose significance increases with increasing freezing rates. Supercooling of the ice base induces also measurable changes in the ice-temperature profile of the glacier. Till porosity represents another quantity whose evolution is influenced strongly by basal freeze-on. In particular, measurements of vertical porosity distribution beneath stopped ice streams could be used to back-calculate the timing of the onset of basal freezing. Our model results show that the basal zone of ice streams and interstream ridges responds sensitively to changes in basal melting/freezing rates. This sensitivity may allow reconstruction of past conditions beneath ice streams and interstream ridges from measurements made on basal ice samples and subglacial sediment samples. Our model results also indicate that meltwater from fast-flowing ice streams may be driven towards the freezing ice base of interstream ridges.
\end{abstract}

\section{INTRODUCTION}

Soft-bedded ice streams are the main control of ice discharge from the Ross Sea sector of the West Antarctic ice sheet (Bentley, 1998; Joughin and Tulaczyk, 2002). Their fast flow arises from subglacial presence of weak till (Alley and others, 1987; Blankenship and others, 1987), which acts as a lubricator between basal ice and the underlying "bedrock" (Kamb, 1991, 2001; Tulaczyk and others, 2000a). This lubrication occurs when pore-water pressure builds up in the till due to a poorly drained subglacial bed. The resulting low effective stress results in a very low frictional resistance (Tulaczyk and others, 2001a). Ice streams may cease to flow fast if the lubricating conditions are lost (Tulaczyk and others, 2000b). Basal freeze-on is an important subglacial mechanism because it may induce water-pressure changes large enough to trigger ice-stream stoppage (Christoffersen and Tulaczyk, in press b). The recent stoppage of Ice Stream C, West Antarctica, may have been caused by a switch from basal melting to basal freezing (Price and Whillans, 2001; Alley, 2002; Joughin and Tulaczyk, 2002).
Slow-moving interstream ridges border the trunks of fastflowing ice streams. Weak subglacial till may not be abundantly present beneath interstream ridges, and the basal ice is generally frozen-based (Gades and others, 2000). Location of the interstream ridges may be thermally controlled by the distribution of basal freezing (Engelhardt and Kamb, 1997; Bentley and others, 1998; Raymond and others, 2001).

Whereas basal melting is a destructive process, basal freezing produces distinct basal ice facies, which can be sampled and analyzed to infer the history of subglacial hydrology (Boulton and Spring, 1986; Souchez and others, 1987). Moreover, basal freezing may lead to characteristic changes in properties of subglacial sediments (Hindmarsh, 1999). Therefore, it is particularly important to quantitatively model processes associated with changes in the basal regime from melting to freezing. Results of such work may improve the conceptual framework for interpretation of past and future borehole and geophysical observations. They may also lead to improved models of ice-stream and ice-sheet dynamics. Here, we present a numerical model that couples ice and sediment thermodynamics. The model 


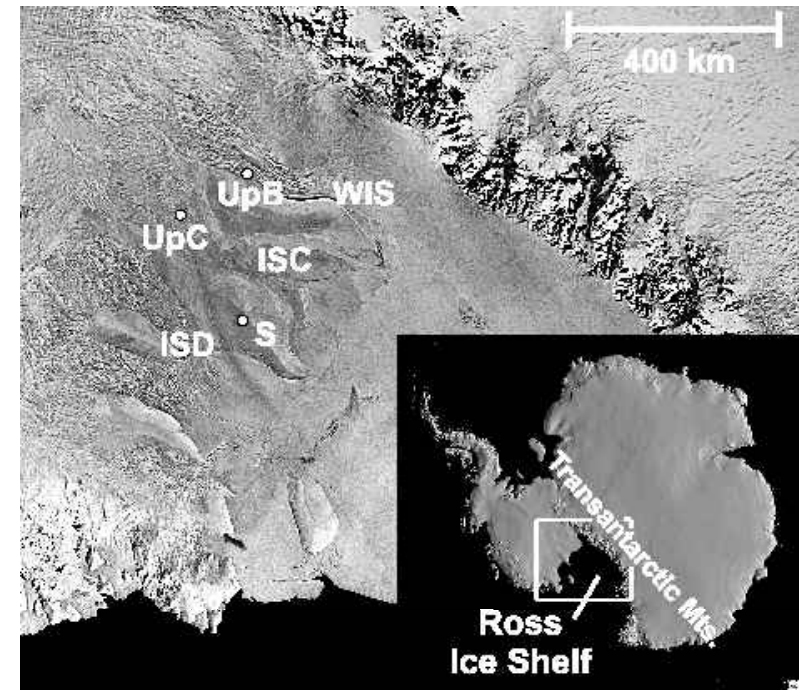

Fig.1. Satellite image of the Ross Sea sector of the West Antarctic ice sheet showing locations of ice streams and interstream ridges (Advanced Very High Resolution Radiometer data distributed by the United States Geological Survey office in Flagstaff, AZ). The drilling sites referred to in the text are: $U p B$ on the active Whillans Ice Stream (WIS), UpC on the stagnant Ice Stream C (ISC), and Siple Dome (S) on the interstream ridge that borders Ice Stream D (ISD). Inset in the lower right corner shows a shaded relief image of the grounded portions of the Antarctic ice sheet. White box gives approximate extent of the main figure.

is used to make testable predictions (e.g. basal ice temperature distribution, subglacial sediment porosity, solute concentration in liquid pore water, isotopic composition of liquid pore water and basal ice).

\section{EXISTING OBSERVATIONAL CONSTRAINTS}

Extensive geophysical studies conducted in the Ross Sea sector of the West Antarctic ice sheet have provided a considerable amount of information about basal and subglacial conditions beneath ice streams and interstream ridges (Blankenship and others, 1986, 1987; Alley and others, 1987; Bentley, 1987, 1998; Bentley and others, 1998). The California Institute of Technology drilling program has subsequently provided detailed observational constraints about the basal zone of this region (Engelhardt and others, 1990; Kamb, 1991; Engelhardt and Kamb, 1997, 1998; Tulaczyk and others, 2000a, 2001a). The location of the Ross Sea region is outlined in Figure 1.

\section{Active ice streams}

Soft-bedded ice-stream conditions were initially inferred from seismic surveys (Blankenship and others, 1986, 1987). Borehole observations from Whillans Ice Stream and Ice Stream D are reported in Kamb (2001). Characteristic observations are here: (1) a finite layer of unfrozen soft and deformable till of $\sim 5 \mathrm{~m}$; (2) basal temperature close to the pressure-melting point, $\sim-0.7^{\circ} \mathrm{C}$ for $1000 \mathrm{~m}$ of ice; (3) basal temperature gradient of $\sim 0.04^{\circ} \mathrm{C} \mathrm{m}^{-1}$; (4) high and uniform till porosity of $\sim 40 \%$ as seen in Figure $2 \mathrm{a}$; (5) low and uniform effective stress of $\sim 1-5 \mathrm{kPa}$; and (6) basal shear strength of $<10 \mathrm{kPa}$ (Tulaczyk and others, 2001a).

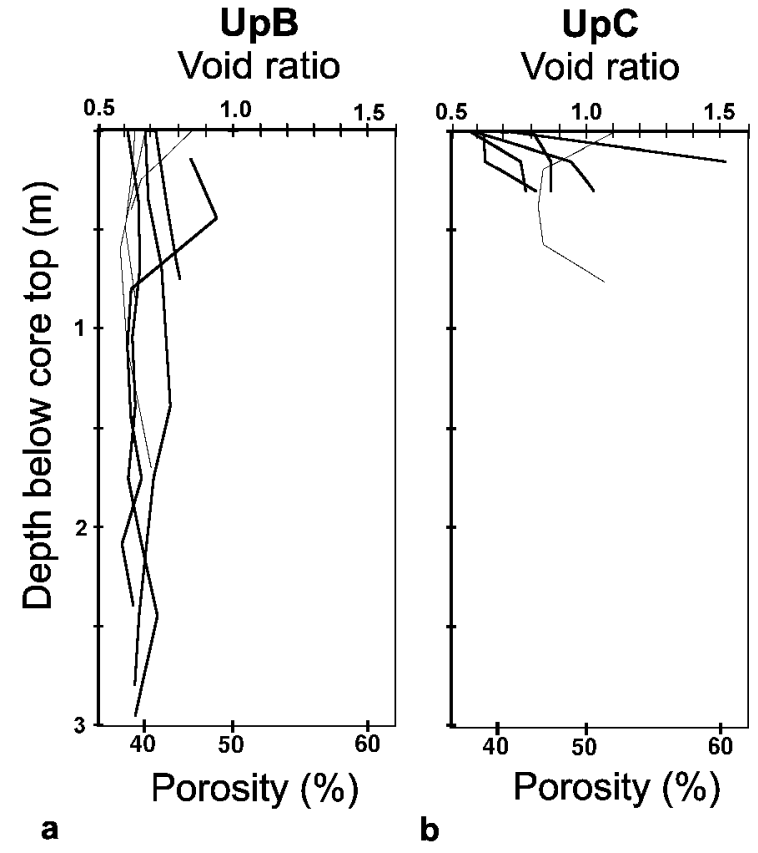

Fig. 2. Diagrams showing vertical porosity distributions measured in sub-ice-stream till cores (Kamb, 2001; Tulaczyk, unpublished data). Relatively constant porosity distribution is observed in the UpB till beneath the fast-flowing Whillans Ice Stream (a). In contrast, porosity distributions in the UpC till beneath the stagnant Ice Stream $C$ decrease by 10-15\% towards the core top ( $b$ ).

Observations from Whillans Ice Stream and Ice Stream $\mathrm{D}$ show that basal conditions are not hydrostatic. Constant porosity distributions with depth, as seen in Figure $2 \mathrm{a}$, indicate lithostatic pressure conditions in the basal zone of fastmoving ice streams (Tulaczyk and others, 2001a).

\section{Stagnant ice streams}

Ice-stream stoppage is triggered when basal resistance is increased to the point where it supports a large fraction of the driving stress (Raymond, 1996; Tulaczyk and others, 2000b; Anandakrishnan and others, 2001; Whillans and others, 2001). An increase in basal shear strength may be caused by an increase in effective stress and a reduction in subglacial water pressure. From boreholes drilled to the base of the stopped Ice Stream C the following relevant observations have been reported (Carsey and others, 2001; Kamb, 2001; Tulaczyk, unpublished data): (1) a relatively steep basal temperature gradient of $\sim 0.05^{\circ} \mathrm{C} \mathrm{m}^{-1}$; (2) vertically extensive layers of debris-bearing accretion ice of $\sim 12-25 \mathrm{~m}$; (3) unfrozen and supercooled subglacial till with a temperature depressed by up to $\sim-0.35^{\circ} \mathrm{C}$ from the pressure-melting point; and (4) upward decrease of till porosity by $\sim 10-15 \%$ difference from core top to core bottom (Fig. 2b).

Several hypotheses have been proposed to explain the recent stoppage of Ice Stream C (Kamb, 1991, 2001; Alley, 1993; Alley and others, 1994; Anandakrishnan and Alley, 1997; Anandakrishnan and others, 2001). Basal freeze-on can either be a cause of ice-stream stoppage (Alley, 2002; Joughin and Tulaczyk, 2002) or occur as a result hereof. Ice-stream shut-down must be associated with a large decrease in basal shear heating, whatever the initial cause of stoppage may be. Detection of an unfrozen bed beneath Ice Stream G, which stopped about 150 years ago, and a partially unfrozen bed 


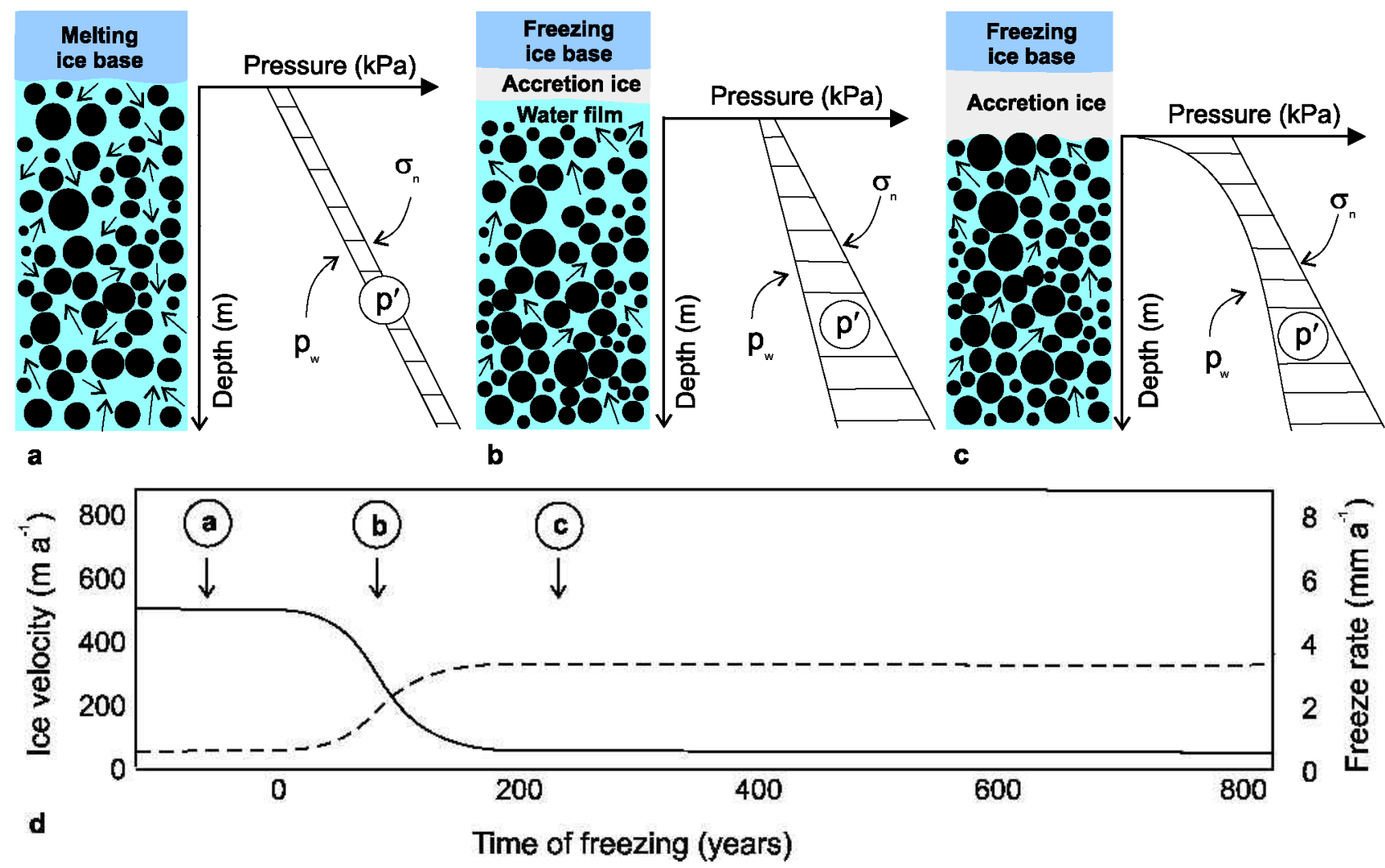

\begin{abstract}
Fig. 3. A conceptual diagram illustrating differences between lithostatic pressure condition (a), hydrostatic pressure condition (b) and cryostatic pressure condition ( $c$ ). The total stress, $\sigma_{\mathrm{n}}$, is a sum of water pressure, $p_{\mathrm{w}}$, and effective pressure, $p^{\prime}$. In ( a) the effective stress is constant due to till mixing by fast ice-stream flow. In $(b)$ the pore-water pressure gradient is reduced due to ice-stream slowdown, a water film develops from hydraulic diffusion and a basal layer of accretion ice develops due to basal freeze-on. In (c) a localized drop in pore-water pressure at the ice-till interface generates non-hydrostatic hydraulic gradients, which drive Darcian water flow out of the till and allow continued growth of the basal ice layer. (d) illustrates the gradual transition between $(a),(b)$ and (c), which occurs during ice-stream stoppage, when ice velocity drops (solid line) and freeze rate increases (dashed line).
\end{abstract}

beneath the Siple Ice Stream, which stopped about 500 years ago, indicate that ice-stream stoppage occurs several centuries before the till layer becomes completely frozen (Bentley and others, 1998; Gades and others, 2000).

\section{Interstream ridges}

Slow-moving interstream ridges border the trunks of ice streams. Edges of these ridges play an important role in icestream dynamics because they take up the high marginal shear stress transferred across ice-stream margins (Raymond, 1996). The location of interstream ridges in the Ross Sea sector appears to be controlled by the spatial distribution of basal freezing and melting (Engelhardt and Kamb, 1997; Kamb, 2001; Raymond and others, 2001; Whillans and others, 2001). However, availability of sediments may also modulate interstream ridge boundaries (Anandakrishnan and others, 1998; Bell and others, 1998). Kamb (2001) summarizes basal conditions observed beneath interstream ridges in the Ross Sea sector: (1) basal temperatures are around $-0.6^{\circ}$ to $-2.5^{\circ} \mathrm{C}$ below the pressure-melting point; (2) basal temperature gradients are of the order of $\sim 0.03-0.05^{\circ} \mathrm{C} \mathrm{m}^{-1}$; and (3) frozen-on, debris-laden basal ice layers are present. Kamb (2001) also reports that piston core damage may indicate impact with solid $\operatorname{rock}(\mathrm{s})$, although frozen sediments may exhibit comparatively high strength values.

\section{THEORETICAL TREATMENT OF THE BASAL ZONE}

The properties of subglacial sediments change in response to switches in the thermal regimen between basal melting and basal freezing (Christoffersen and Tulaczyk, in press a). The coupling between thermal changes and physical properties in the basal zone may have a profound effect upon ice dynamics (Bougamont and others, in press). Here, we have simplified the theoretical treatment of basal freeze-on in order to (1) study long-term effects (up to 125000 years) and (2) make testable predictions that can be related directly to borehole observations. Our numerical analysis of ice--water-sediment interaction contains three different pressure conditions, which are outlined in Figure 3. Lithostatic pressure conditions are found in the till layer beneath active ice streams (Fig. 3a). Hydrostatic pressure conditions should arise during ice-stream slow-down (Fig. 3b). Cryostatic pressure conditions are associated with ice-stream stagnation and subsequent dewatering of till due to basal freeze-on (Fig. 3c). These cases are associated with different stages of ice streaming, i.e. fast flow, slowdown and complete shut-down (Fig. 3d).

\section{Ice-stream mode: till mixing and lithostatic pressure condition}

Tulaczyk and others (2001b) proposed that the lithostatic pressure distribution beneath fast-flowing ice streams is caused by intermittent or continuous subglacial till deformation that 
reaches several meters into the bed. Continuous till deformation is not necessary due to the long hydraulic relaxation time of fine-grained sub-ice-stream till with characteristic diffusive time-scale of approximately 25 years. Intermittent till deformation can produce the inferred lithostatic water-pressure distribution because the mixing, if vigorous enough, will work against the normal tendency of pore water to achieve hydrostatic water-pressure distribution (Fig. 3a).

Force balance in saturated porous media is usually given by (Mitchell, 1993, p. 315):

$$
p_{\mathrm{n}}=p^{\prime}+p_{\mathrm{w}}=p^{\prime}+p_{\mathrm{h}}+u,
$$

where $p_{\mathrm{n}}$ is gravitational overburden pressure, $p^{\prime}$ effective pressure and $p_{\mathrm{w}}=p_{\mathrm{h}}+u$ is the water pressure, where $p_{\mathrm{h}}$ is the hydrostatic water-pressure component and $u$ is the excess water-pressure component. Water flow is driven by hydraulic gradients, which may be expressed through excess, rather than total, water pressure (Mitchell, 1993, p. 315). When till deforms in the lithostatic-pressure case, we derive the vertical distribution of excess water pressure, $u$, by adding a parameterized mixing term to the customary hydraulic diffusion equation, which is used for flow in non-deforming sediments (Mitchell, 1993, equation 13.19). Hence,

$$
\frac{\partial u}{\partial t}=c_{\mathrm{v}} \frac{\partial^{2} u}{\partial z^{2}}-f U_{\mathrm{b}} \frac{\partial u}{\partial z},
$$

where $c_{\mathrm{V}}$ is hydraulic diffusivity, $t$ is time, $z$ is depth below ice-till interface, $U_{\mathrm{b}}$ is basal ice velocity, and $f$ is a constant for our hypothesized mixing term. The value of $f$ is chosen so that mixing is important only when the basal velocity is high $\left(>100 \mathrm{~m} \mathrm{a}^{-1}\right)$. As ice-stream velocity decreases, the mixing term of Equation (2) becomes increasingly insignificant, and the system adjusts toward hydrostatic conditions through hydraulic diffusion. When till mixing ceases, the rate of vertical water flow is prescribed by Darcy's flow law (Domenico and Schwartz, 1990, equation 4.53):

$$
v_{\mathrm{w}}=-c_{\mathrm{v}} \frac{\partial u}{\partial z} \text {. }
$$

The transition to hydrostatic conditions through hydraulic diffusion is associated with expulsion of excess pore water that was present in the till under lithostatic conditions (Fig. $3 \mathrm{~b})$. The excess water may be drained away through a basal water system or it may pond at the ice-till interface until it is consumed by basal freeze-on. Decimetre-thick basal water layers have been observed in boreholes drilled near the paleo-ice-stream margin of Ice Stream $\mathrm{C}$ in the vicinity of the UpC camp (Carsey and others, in press).

\section{Ice-sheet mode: basal freeze-on and cryostatic pressure condition}

When freeze-on exceeds the hydraulic capability of a distributed basal water system, a cryostatic pressure distribution develops in the till. Cryostatic suction, which has been studied extensively by permafrost engineers, plays an important role in numerical frost-heave simulations (O'Neill and Miller, 1985; Konrad and Duquennoi, 1993; Fowler and Krantz, 1994; Miyata, 1998; Nakano, 1999). The phenomenon is analogous to the more commonly known capillary suction, as freezing and thawing in a saturated porous medium is physically similar to wetting and drying in a partially saturated porous medium (Fowler and Krantz, 1994).

Pore water in fine-grained porous media becomes supercooled when pore spaces are too small for ice crystal growth. The inhibition of ice growth in fine-grained sediments stems from ice--water interfacial curvature effects related to surface tension arising from micron-sized pore spaces (Tester and Gaskin, 1996; Hohmann, 1997). The surface tension of West Antarctic sub-ice-stream till has been estimated as $104 \mathrm{kPa}$ (Tulaczyk, 1999), although this value is likely to be an underestimate since the calculation assumed that all particles are spheres. In reality, a large fraction of particles are platy clays, which can have much greater area-to-volume ratios than that of a sphere. For ice to form within subglacial sediments, the ice pressure must exceed the gravitational overburden pressure plus the surface tension (Hopke, 1980; O’Neill and Miller, 1985; Konrad and Duquennoi, 1993; Fowler and Krantz, 1994).

Ice-water phase equilibrium is prescribed by the Clapeyron equation, which is a general thermodynamic relation, not specific to our purpose. Liquid water freezes when the pressure components and the temperature satisfy a generalized form of the Clapeyron equation (O'Neill and Miller, 1985; Padilla and Villeneuve, 1992):

$$
\frac{p_{\mathrm{w}}}{\rho_{\mathrm{w}}}-\frac{p_{\mathrm{i}}}{\rho_{\mathrm{i}}}=\frac{L}{273.15} T+\frac{p_{\mathrm{o}}}{\rho_{\mathrm{w}}},
$$

where $p_{\mathrm{w}}$ is the water pressure, $p_{\mathrm{i}}$ is the ice pressure, $p_{\mathrm{O}}$ is the osmotic pressure, $\rho_{\mathrm{w}}$ is the density of water, $\rho_{\mathrm{i}}$ is the density of ice, $L$ is the coefficient of latent heat of fusion and $T$ is the temperature in ${ }^{\circ} \mathrm{C}$.

When ice crystal growth is inhibited inside fine-grained sub-ice-stream tills, the response to freezing is a reduction in pore-water pressure at the freezing interface. Instead of freezing within the pore spaces, liquid water flows towards the freezing interface where it accretes into a layer of segregation ice (O’Neill and Miller, 1985; Konrad and Duquennoi, 1993). Subglacial freezing thus induces yet another characteristic pressure distribution in the sub-ice-stream till. Based on permafrost terminology, we call this the cryostatic pressure distribution (Fig. 3c). This pressure distribution occurs when the ice stream is in a stagnant ice-sheet-like stage where the till does not deform and till pore water flows toward the freezing ice base.

Heat and solutes are transported vertically in the till by diffusion as well as advection. The transport equation for both variables is a standard diffusion-advection equation (Domenico and Schwartz, 1990, p. 472):

$$
\frac{\partial X}{\partial t}=\kappa_{X} \frac{\partial^{2} X}{\partial z^{2}}-v_{\mathrm{w}} \frac{\partial X}{\partial z},
$$

where $X$ is the variable ( $T$ for temperature and $C$ for solute concentration), $\kappa_{X}$ is the respective diffusion coefficient, and $v_{\mathrm{w}}$ is the water flow rate from Equation (3).

Isotopic compositions are derivable from the redistribution of solutes during freezing (Souchez and Lorrain, 1991, p. 46 and 55), and for simplicity we assume that all solutes are rejected from liquid pore water that freezes.

The above equations are fundamental for treating the response of subglacial sediments to basal freeze-on. Quantitative treatment of the combined effect of supercooling, thermally driven hydraulic gradients, and the flow of water, heat and solutes is needed in order to infer the history of subice-sheet hydrology from basal ice facies.

\section{THEORETICAL TREATMENT OF IGE DYNAMIGS}

By assumption, steady ice-stream flow is restricted to periods 
of basal melting. Whereas basal melting is an inherently destructive process, basal freeze-on leaves a record of subglacial hydrology (Boulton and Spring, 1986). Basal freeze-on also leaves a record of thermal conditions in the basal zone. Slow-moving ice sheets and interstream ridges are not influenced significantly by frictional heat due to the absence of basal sliding. Here, physical changes in the basal zone stem from climatic changes at the ice-sheet surface. Climatic signals from fluctuations in air temperature and accumulation rate are, however, dampened significantly by thermal diffusion when the ice thickness is large (Alley and others, 1997). The effect of temperature on strain rate in ice is important when modeling the downward propagation of oscillating surface temperatures. For calculation of the temperature-dependent strain rate, $\dot{\varepsilon}$, we use (Hooke, 1998, equation 4.8):

$$
\dot{\varepsilon}=\dot{\varepsilon}_{0} \exp (k T),
$$

where $\dot{\varepsilon}_{0}$ is a reference strain rate, $k=0.25^{\circ} \mathrm{C}^{-1}$ is a constant, and $T$ is the temperature, taken here for simplicity to be the weighted mean $\bar{T}=\left(T_{\mathrm{i}}-T_{\mathrm{pmp}}\right)(h-z) / h$, where $z$ is height above bed and $h$ is ice thickness.

The elevation change accompanying changes in surface temperature and accumulation rate, $b$, is (Paterson, 1994, p. 256-257):

$$
\frac{\partial h}{\partial t}=b-\dot{m}-h \dot{\varepsilon},
$$

where $\dot{m}$ is the basal melting rate. The vertical ice velocity at the ice-sheet surface is thus $w_{\mathrm{s}}=-b-\dot{m}+\partial h / \partial t$. The icetemperature changes induced by climatic variation can be derived from a diffusion-advection equation of the form (Paterson, 1994, p. 216):

$$
\frac{\partial T_{\mathrm{i}}}{\partial t}=\kappa_{\mathrm{i}} \frac{\partial^{2} T_{\mathrm{i}}}{\partial z^{2}}-U_{z} \frac{\partial T_{\mathrm{i}}}{\partial z},
$$

where $T_{\mathrm{i}}$ is ice temperature, $\kappa_{\mathrm{i}}$ is the thermal diffusivity of ice and $U_{z}=w_{\mathrm{s}}(z / h)^{2}$ is the vertical ice velocity (Paterson, 1994, p. 220). The basal heat budget is (Alley and others, 1997):

$$
G-\theta_{\mathrm{b}} K_{\mathrm{i}}+\tau_{\mathrm{b}} U_{\mathrm{b}}-\rho_{\mathrm{i}} \dot{m} L=0,
$$

where $G$ is geothermal heat flux, $\theta_{\mathrm{b}}$ is the basal temperature gradient, $K_{\mathrm{i}}$ is thermal conductivity of ice, $\tau_{\mathrm{b}}$ is the basal shear stress, which is given by the Mohr-Coulomb failure criterion when smaller than the driving stress $\tau_{\mathrm{d}}, U_{\mathrm{b}}$ is basal ice velocity given by Raymond (1996, equation 38) or Tulaczyk (2000a, equation 15), and $L$ is coefficient for latent heat of fusion.

\section{NUMERICAL EXPERIMENTS}

Here we present two numerical experiments. The first experiment simulates changes in the basal zone during ice-stream stagnation accompanied/triggered by basal freeze-on. The second numerical experiment simulates changes in the basal zone of an interstream ridge induced solely by climatic signals. The model contains two numerical modules: (1) an ice column represented by 51 nodes, and (2) a till column represented by 101 nodes. The two modules are coupled via heat balance and mass balance. In our ice-stream simulations, basal freeze-on is induced by prescribing a basal temperature gradient that is just steep enough to generate a slightly negative basal energy balance. This perturbation triggers a runaway process in which latent heat gradually replaces frictional heat in the basal heat balance. With the equations outlined above, we study the associated changes in subglacial

\begin{tabular}{|c|c|c|c|}
\hline Symbol & Value/units & Definition & Description \\
\hline$C$ & {$[3,3] \%$} & $\begin{array}{l}\text { Solute concentration in } \\
\text { till }\end{array}$ & Model variable \\
\hline$c_{\mathrm{V}}$ & $10^{-8} \mathrm{~m}^{2} \mathrm{~s}^{-1}$ & Hydraulic diffusivity, till & Constant \\
\hline$f$ & $1 \times 10^{-3}$ & Till mixing constant & Constant \\
\hline$H_{\mathrm{i}}$ & $1000 \mathrm{~m}$ & Ice thickness & Constant \\
\hline$\dot{m}$ & $-0.13 \mathrm{~mm} \mathrm{a}^{-1}$ & Melting rate & $\begin{array}{c}\text { Time-dependent } \\
\text { parameter }\end{array}$ \\
\hline$K_{\mathrm{h}}$ & $10^{-10} \mathrm{~m} \mathrm{~s}^{-1}$ & $\begin{array}{c}\text { Hydraulic conductivity, } \\
\text { till }\end{array}$ & Constant \\
\hline$K_{\mathrm{i}}$ & $2.1 \mathrm{~J} \mathrm{~s}^{-1} \mathrm{~m}^{-1} \mathrm{~K}^{-1}$ & Thermal conductivity, ice & Constant \\
\hline$T$ & {$[-0.66,-0.45]^{\circ} \mathrm{C}$} & Temperature in till & Model variable \\
\hline$T_{\mathrm{i}}$ & {$[-25,-0.66]^{\circ} \mathrm{C}$} & Temperature in ice & $\begin{array}{l}\text { Time-dependent } \\
\text { parameter }\end{array}$ \\
\hline$u$ & {$[-1.8,-1.8] \mathrm{kPa}$} & $\begin{array}{c}\text { Excess water pressure in } \\
\text { till }\end{array}$ & Model variable \\
\hline$U_{\mathrm{b}}$ & $460 \mathrm{~m} \mathrm{a}^{-1}$ & Ice-stream velocity & $\begin{array}{c}\text { Time-dependent } \\
\text { parameter }\end{array}$ \\
\hline$W$ & $36 \times 10^{3} \mathrm{~m}$ & Ice-stream width & Constant \\
\hline$\varphi$ & {$[40,40] \%$} & Till porosity & $\begin{array}{l}\text { Time-dependent } \\
\text { parameter }\end{array}$ \\
\hline$\tau_{\mathrm{b}}$ & $2.7 \mathrm{kPa}$ & Basal shear strength & $\begin{array}{l}\text { Time-dependent } \\
\text { parameter }\end{array}$ \\
\hline$\tau_{\mathrm{d}}$ & $13 \mathrm{kPa}$ & Driving stress & Constant \\
\hline$\kappa_{\mathrm{c}}$ & $8 \times 10^{-11} \mathrm{~m}^{2} \mathrm{~s}^{-1}$ & Chemical diffusivity, till & Constant \\
\hline$\kappa_{\mathrm{i}}$ & $1.2 \times 10^{6} \mathrm{~m}^{2} \mathrm{~s}^{-1}$ & Thermal diffusivity, ice & Constant \\
\hline$\kappa_{\mathrm{T}}$ & $7.6 \times 10^{-7} \mathrm{~m}^{2} \mathrm{~s}^{-1}$ & Thermal diffusivity, till & Constant \\
\hline
\end{tabular}
pressure distribution, porosity distribution, solute concentra-
Table 1. List of constants, time-dependent parameters and model variables in the ice-stream simulation

Notes: Values listed for time-dependent parameters and variables are initial values. Depth-dependent properties are listed in the format $[x, y]$, where $x$ is the value at the top of the domain and $y$ is the lowermost value.

tion, basal ice formation and isotopic composition. In both experiments equilibrium freeze-on is obtained because we assume that water can be added to the simulated ice-sediment system from a ground-water source below the till. This source may be Tertiary glaciomarine diamictons found abundantly

\begin{tabular}{|c|c|c|c|}
\hline Symbol & Value/units & Definition & Description \\
\hline$b$ & $0.12 * \mathrm{~m} \mathrm{a}^{-1}$ & Accumulation rate & $\begin{array}{c}\text { Time-dependent } \\
\text { parameter }\end{array}$ \\
\hline$C$ & {$[3,3] \%$} & $\begin{array}{l}\text { Solute concentration in } \\
\text { sediment }\end{array}$ & Model variable \\
\hline$H_{\mathrm{i}}$ & $1000 \mathrm{~m}$ & Ice thickness & $\begin{array}{l}\text { Time-dependent } \\
\text { parameter }\end{array}$ \\
\hline$\dot{m}$ & $0.13 \mathrm{~mm} \mathrm{a}^{-1}$ & Basal melting rate & $\begin{array}{l}\text { Time-dependent } \\
\text { parameter }\end{array}$ \\
\hline$T$ & {$[-0.66,1.5]{ }^{\circ} \mathrm{C}$} & Temperature in sediment & Model variable \\
\hline$T_{\mathrm{i}}$ & {$\left[-25^{*},-0.66\right]^{\circ} \mathrm{C}$} & Temperature in ice & $\begin{array}{c}\text { Time-dependent } \\
\text { parameter }\end{array}$ \\
\hline$u$ & {$[-50,-50] \mathrm{kPa}$} & $\begin{array}{c}\text { Excess water pressure in } \\
\text { sediment }\end{array}$ & Model variable \\
\hline$\dot{\varepsilon}$ & $2.8 \times 10^{-4} \mathrm{~s}^{-1}$ & Strain rate of ice & $\begin{array}{c}\text { Time-dependent } \\
\text { parameter }\end{array}$ \\
\hline$\varphi$ & {$[40,28] \%$} & Sediment porosity & $\begin{array}{c}\text { Time-dependent } \\
\text { parameter }\end{array}$ \\
\hline
\end{tabular}
in the Ross Sea basin (Anderson, 1999) and inferred to be pres-

Table 2. List of constants, time-dependent parameters and model variables in the interstream ridge simulation

Notes: Values listed for time-dependent parameters and variables are initial values. Depth-dependent properties are listed $[x, y]$, where $x$ is the value at the top of the domain and $y$ is the lowermost value. Climatic parameters whose values are varied using the Vostok ice-core data are marked

*. Ice and sediment properties are the same as listed in Table 1. 


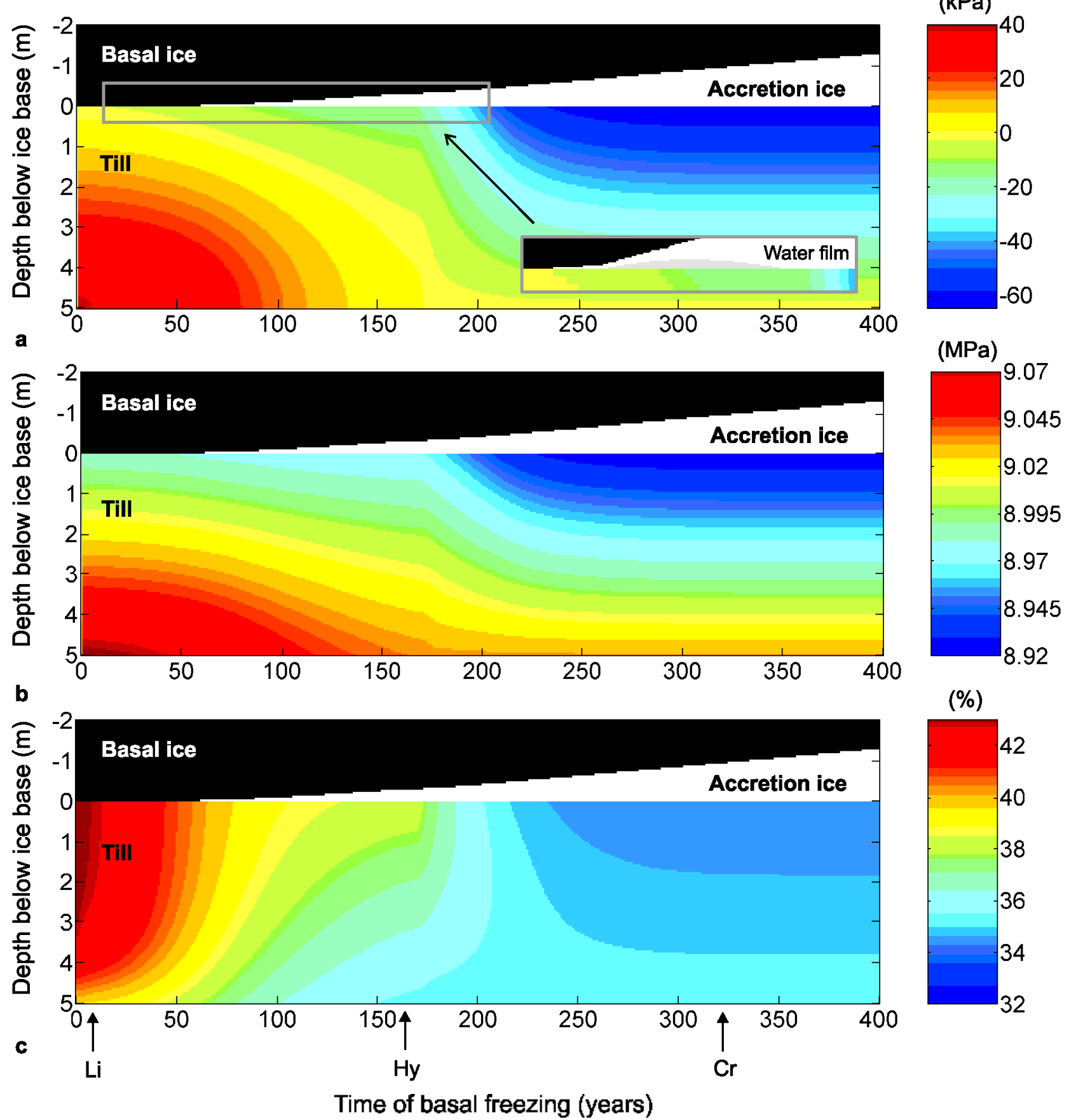

Fig. 4. Depth-time diagrams illustrating changes in the basal zone during ice-stream stagnation. Glacier ice is shown in black, and the accreted basal ice layer is shown in white. The colour scale denotes vertical distribution of: (a) excess pore-water pressure $(\mathrm{kPa}),(\mathrm{b})$ total pore-water pressure (MPa), and (c) porosity (\%). Label "Li" refers to lithostatic conditions, "Hy" to hydrostatic conditions, and "Cr" to cryostatic conditions.

ent beneath much of the grounded portions of the West Antarctic ice sheet, including the $\mathrm{UpB}$ area of Whillans Ice Stream (Rooney and others, 1991; Tulaczyk and others, 1998; Studinger and others, 2001).

\section{Experiment 1: ice stream}

Here, our aim is to study the transition from lithostatic to hydrostatic, and finally to cryostatic, pressure distribution in a sub-ice-stream till layer with a finite thickness of $5 \mathrm{~m}$. Due to a relatively modest time-scale of this model run (1000 years) we keep the ice thickness and the surface temperature constant. The subglacial changes are induced solely by the changes in ice dynamics due to ice-stream slow-down. The model is set up to emulate the well-studied UpB basal zone of Whillans Ice Stream. This numerical simulation builds on the undrained plastic bed model proposed by Tulaczyk and others (2000b). Here, an initial, infinitesimal basal perturbation in basal freezing is sufficient to bring the ice-till system into an unstable state, which results in shutdown of the ice stream. We use the modern climate record to induce a steady-state temperature profile in the ice. Values for constant properties and initial values for time-dependent parameters and model variables are listed in Table 1 . The initial fast-ice velocity is $460 \mathrm{~m} \mathrm{a}^{-1}$.

\section{Experiment 2: interstream ridge}

In this case, we study changes in the basal zone of an interstream ridge over the last glacial-interglacial cycle. In con- 


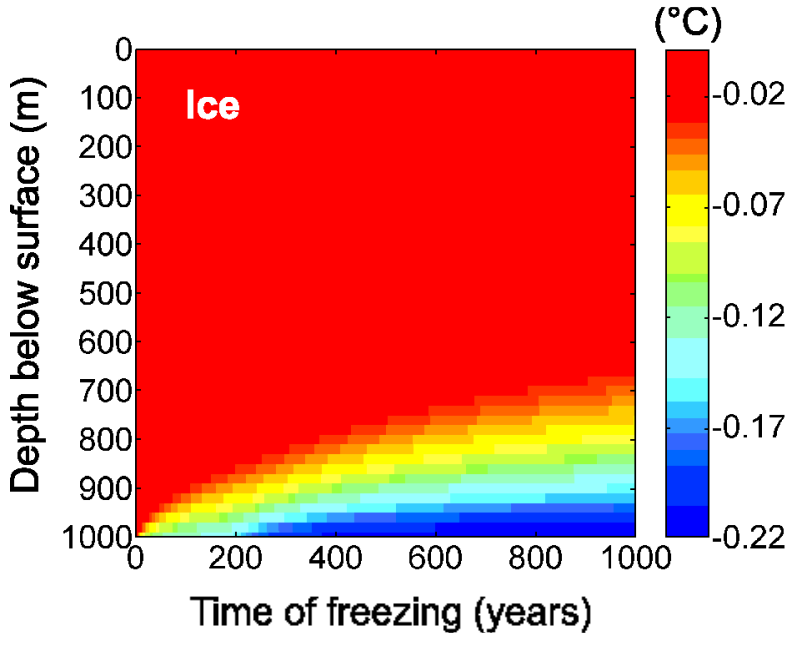

Fig. 5. Depth-time diagram illustrating changes in ice temperature induced by subglacial supercooling and basal freezeon. The colour scale denotes the difference between simulated ice-temperature distribution and the initial ice-temperature distribution at the onset of freezing.

trast to the previous case, we include sub-till sediments into a basal zone that is $50 \mathrm{~m}$ thick. Having a thick sedimentary sequence allows us to estimate how deep freeze-on-induced pressure changes can propagate from the ice--sediment interface. Based on the paleoclimatic record from the Vostok ice core (Petit and others, 1999), we simulate the behavior of an ice divide within an interstream ridge over the last 125000 years. We assume a constant geothermal heat flux. Variations in the heat budget are therefore controlled by the climatic surface signal, which causes the fluctuations in the basal temperature gradient, and latent heat released through freeze-on during cold-based periods. Values for constant properties and initial values for time-dependent parameters and model variables are listed in Table 2.

\section{RESULTS}

Experiment 1: signatures at the base of a stopped ice stream

When ice-stream flow ceases, significant changes take place in the subglacial pressure system. Results of our calculations are presented in Figure 4, which illustrates changes in the basal zone during the first 400 years of basal freezing. During the remaining 600 model years, no major changes occur since the model has reached a quasi-steady state. During the simulation, basal freeze-on extracts subglacial water from the lubricating bed, and a layer of accretion ice develops. The bed strengthens due to dewatering of the till. Slow-down of the ice stream brings an end to significant till mixing ( $\sim 9$ years of freezing), and the basal zone starts adjusting to hydrostatic pressure conditions. Excess pore water flows upward from the lower part of the till during the transition from lithostatic to hydrostatic conditions (Fig. 4a). In our model, the expulsion of pore water produces a water film at the ice-till interface as long as the basal freezing rate is smaller than the rate of pore-water discharge. In the presented case, the film attains a maximum thickness of $58 \mathrm{~mm}$ (at $\sim 100$ years of freezing). Eventually, basal freeze-on consumes the water film ( 158 years of freezing). At this point, the subglacial pressure system is hydrostatic. However, another pressure condition arises, when free basal water in a film (or distributed basal water system) is no longer present at the ice-till interface. This shortage of water creates a deficit in the basal heat budget. Hence, the ice base, together with the liquid pore water at the top of the till, becomes supercooled. In response to supercooling, a cryostatic flow of pore water arises in the till
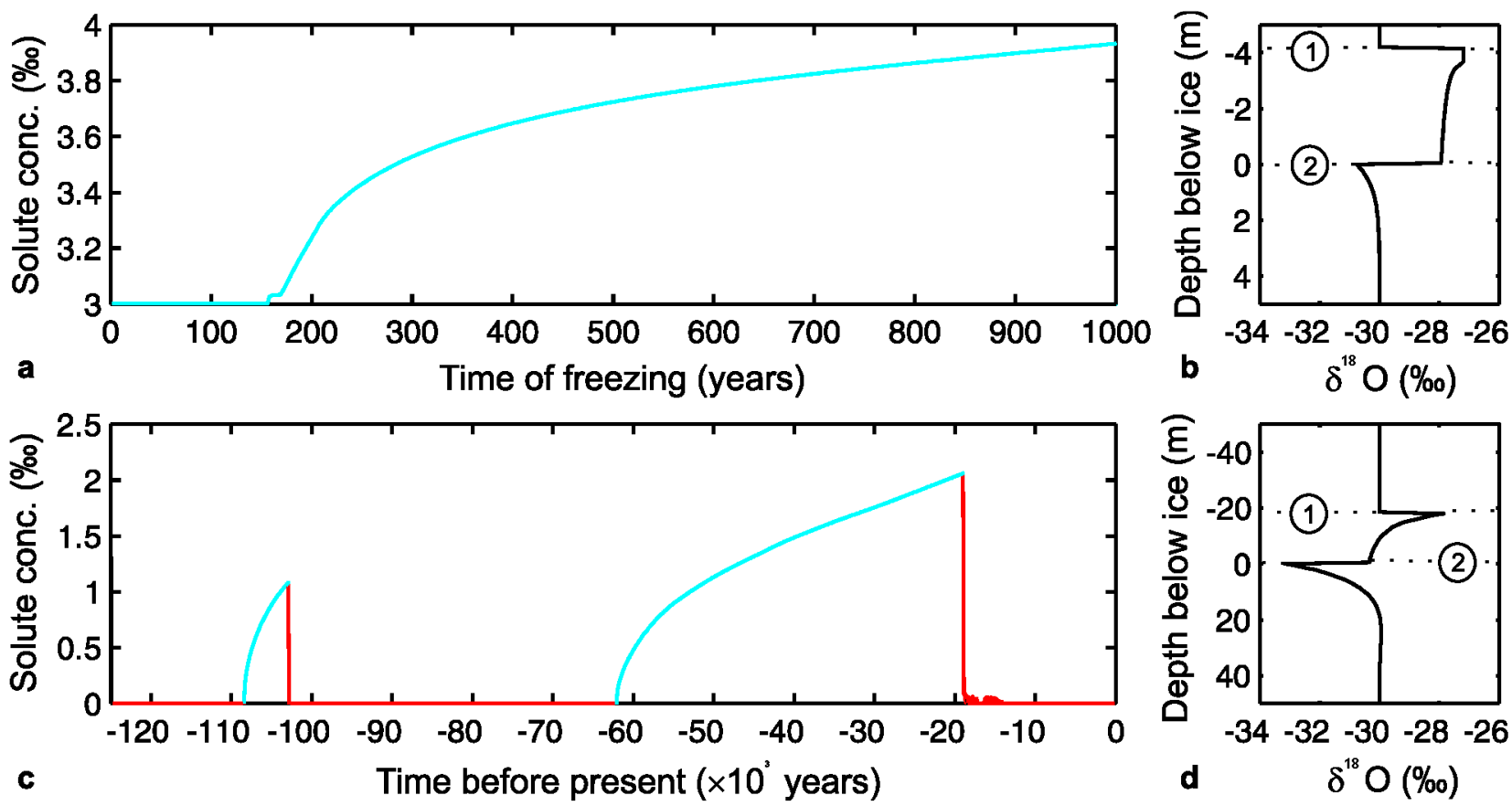

Fig. 6. Diagrams illustrating geochemical effects of basal freezing (blue) and basal melting (red): (a) increase in solute concentration at the ice-till interface beneath a stopping ice stream; (b) vertical $\delta^{18} \mathrm{O}$ profile in basal ice and subglacial till after 1000 years of basal freezing; $(c)$ changes in solute concentration at the ice-till interface of an interstream ridge; $(d)$ vertical $\delta^{18} O$ profile in basal ice and till beneath the simulated interstream ridge prior to Holocene basal melting. Label (1) designates the transition between glacier ice and accretion ice, while (2) is the ice-till interface. 

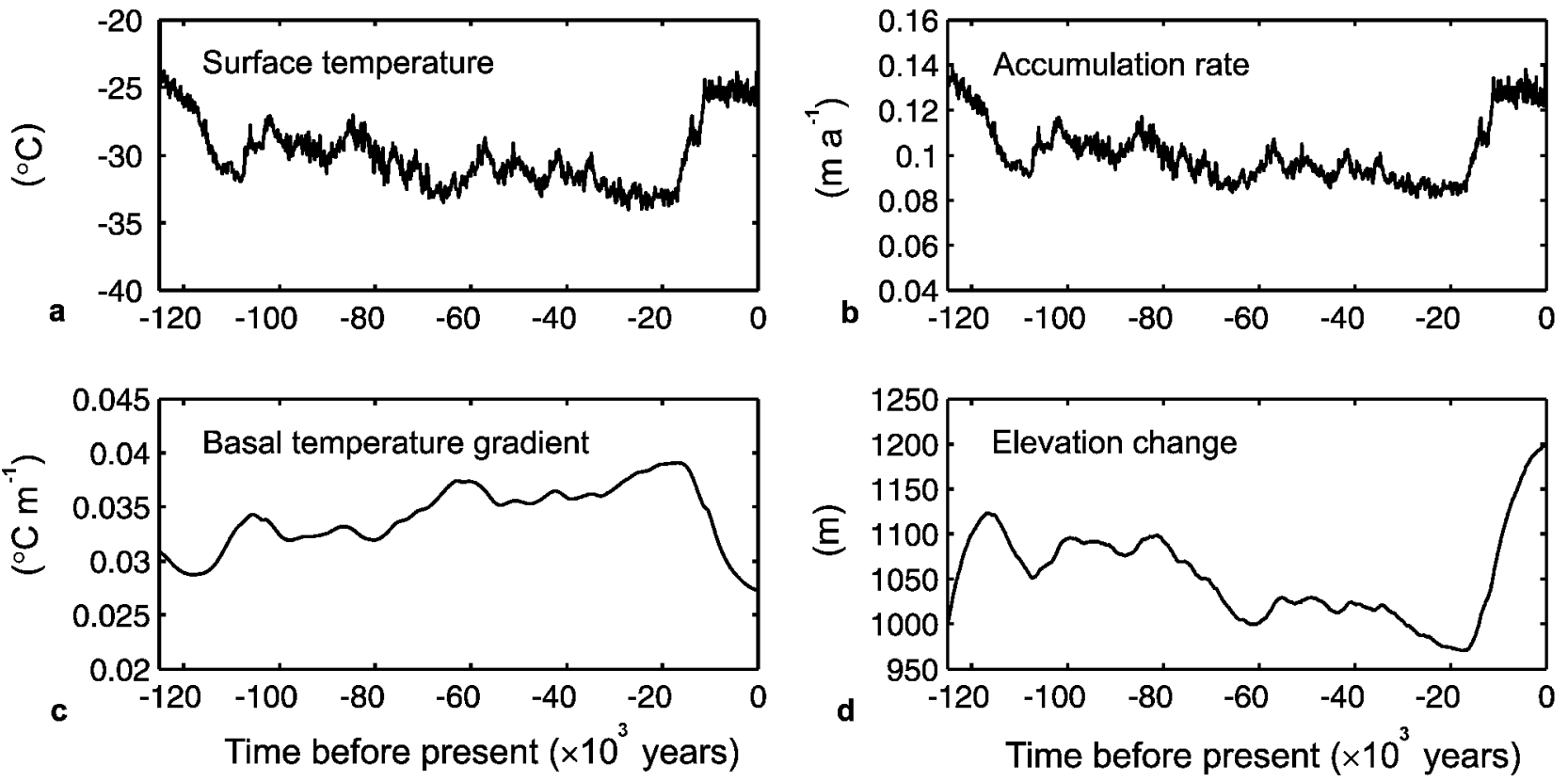

Fig. 7. Model results displaying ice-sheet response to variations in surface temperature ( a) and accumulation rate (b) (based on paleoclimatic record from the Vostok ice core by Petit and others (1999)). Illustrated here are changes in the basal temperature gradient (c) and ice-thickness changes (d) during a full glacial cycle of 125000 years.

( 175 freezing years). This marks a fairly abrupt change in the basal zone, as seen in Figure $4 \mathrm{a}-\mathrm{c}$. The ice stream comes to a complete stop. Thermally driven hydraulic gradients arise, and basal freeze-on starts to consume pore water extracted from the till. After an additional 85 years ( 260 freezing years), a cryostatic equilibrium is obtained because the hydraulic gradient is large enough to withdraw water from the sedimentary source below the till. At this stage, the total pore-water pressure has been lowered by $>60 \mathrm{kPa}$ (Fig. 4b). The associated increase in effective pressure results in a porosity reduction from $40 \%$ to about $32 \%$ (Fig. $4 \mathrm{c}$ ).

An interesting effect of basal freeze-on is that the thermodynamic processes at the ice-till interface leave a record in the overlying ice. The basal supercooling associated with the shortage of free basal water diffuses into the ice-temperature profile. Figure 5 shows how this basal signal propagates into the lower $300 \mathrm{~m}$ of glacier ice. Measurements of temperatures near the base of an ice stream experiencing freeze-on may provide a basis for estimating when basal freezing was initiated. This could help determine whether basal freeze-on is just a result or a cause of ice-stream stoppage.

After a few centuries ( $>260$ years), there are no significant changes in the ice-till system since the upward transport of sub-till water matches the growth rate of basal ice $\left(\sim 4.5 \mathrm{~mm} \mathrm{a}^{-1}\right)$. The basal ice layer gains a thickness of $4.2 \mathrm{~m}$ over 1000 years of basal freezing. Figure 6 a illustrates how solutes accumulate at the ice-till interface due to rejection of solutes during the freezing process. High concentration of solutes near an ice base could provide another indication of basal freeze-on, if appropriate measurements can be made in subglacial sediments. Since solute diffusion and advection are well-quantified processes, data on vertical distribution of solute concentration in subglacial sediments may be potentially used to back-calculate the timing of initiation of basal freeze-on. Extraction of sediment pore water by basal freeze-on should also leave a signal in the stable-isotope composition of basal ice and subglacial pore water. Rayleigh fractionation will change with time the isotopic make-up of both substances (Fig. 6b).
Experiment 2: signatures in the basal zone of interstream ridges

Physical changes in the basal zone of interstream ridges are subtle due to the absence of frictional heat in the basal heat budget. Nevertheless, our modeling of an interstream ridge also shows considerable changes in the basal zone because freezing acts over long periods of time. Figure 7 shows fluctuations in surface temperature (Fig. 7a) and accumulation rate (Fig. 7b) since the last interglacial period 125000 years ago. We use these data to force the temporal evolution of the ice-temperature field in our calculations. The temperature record is from the Vostok ice core (Petit and others, 1999), and changes in accumulation rate have been calculated using a common assumption of $5.3 \%$ of decrease in accumulation with each degree of cooling (Van der Veen, 1999, equation 11.5.14). We have assumed that the reference accumulation rate is $0.122 \mathrm{~m} \mathrm{a}^{-1}$ of pure ice at the present-day temperature of Siple Dome (Hamilton, 2002). These climatic variations influence the basal zone despite significant dampening of the surface signal. The calculated changes in the basal temperature gradient are $\sim 5000$ years out of phase with the surface conditions (Fig. 7c).

The climatic forcing applied in this simulation (Fig. 7a and b) triggers two periods of basal freezing (Fig. 8). A small freezing event occurs at $\sim 108 \mathrm{kyr}$ BP but it lasts for $<5 \mathrm{kyr}$ and has only small effects. The second, major freezing event starts at $\sim 62 \mathrm{kyr}$ BP and lasts for approximately 45 kyr. Figure $8 \mathrm{a}$ shows that this event influences excess pore-pressure distribution to depths of $>40 \mathrm{~m}$ even though the freezing rate never exceeds $1 \mathrm{~mm} \mathrm{a}^{-1}$. Figure $8 \mathrm{~b}$ illustrates changes in the total pore-water pressure, which reflect variations in excess pore pressure shown in Figure $8 \mathrm{a}$ but also mirror ice-thickness changes (up to $230 \mathrm{~m}$, as seen in Fig. $7 d$ ). High levels of effective pressure may occur in the upper part of the sedimentary column due to cryostatic suction, and the porosity may thus decrease from $40 \%$ to $\sim 35 \%$ at the ice-till interface (Fig. 8c).

The accreted basal ice layer attains its maximum thick- 


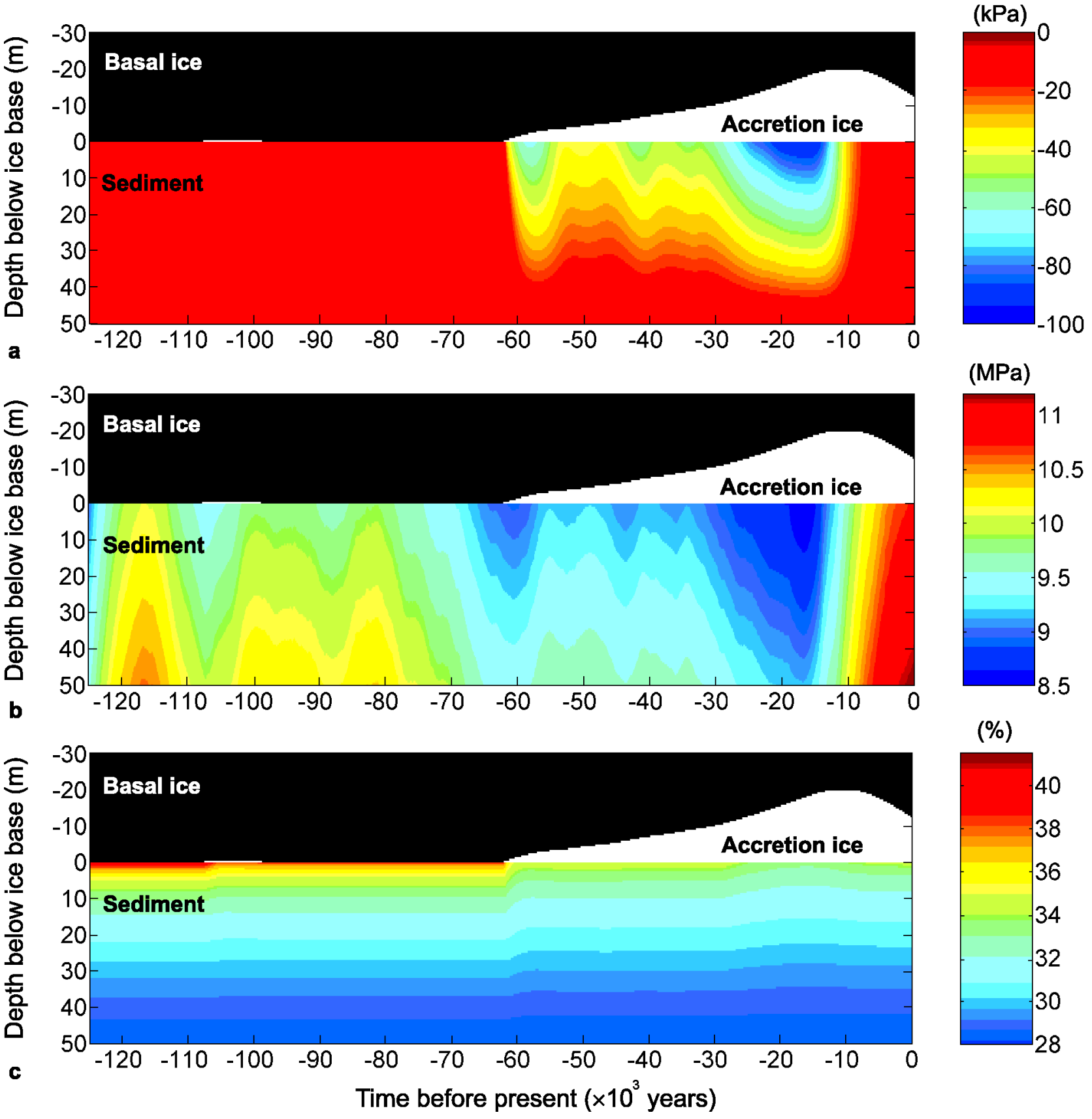

Fig. 8. Depth-time diagrams illustrating pressure and porosity changes in the basal zone of an interstream ridge during the last 125000 years. Glacier ice is shown in black, and the accreted basal ice layer is shown in white. (a), (b) and (c) correspond to the cases described in the caption of Figure 4.

ness of $19.9 \mathrm{~m}$ just after the Last Glacial Maximum (at $\sim 15000 \mathrm{BP}$ ). The subsequent switch to basal melting reduces the thickness of the basal layer to $12.1 \mathrm{~m}$. This result demonstrates that climatically driven basal freeze-on beneath interstream ridges may produce an accreted basal ice layer, which is as thick as the basal layers observed at the base of Ice Stream G (Engelhardt, 2001; Carsey and others, in press). The water used up in generation of these layers comes, in our model, both from extraction of pre-existing sediment pore water and from a deeper ground-water source. Freeze-on-induced depression of subglacial water pressures may be sufficient to drive regional ground-water flow that brings meltwater generated at the base of active ice streams to the basal zones of interstream ridges. Subsequent incorporation of ice from interstream ridges into active ice streams may give rise to thick layers of sedimentladen basal ice, such as those found near camp UpC (Carsey and others, in press).
While the total amount of basal accretion is $20.3 \mathrm{~m}$ during the entire glacial cycle, the total amount of basal melt is $23.1 \mathrm{~m}$. As expected, initial melting rate is relatively fast due to interglacial conditions. However, basal melting is also fast at the end of the model run, i.e. in the simulated late Holocene. This is not a realistic result since measurements show ice below pressure-melting temperature at the base of at least two interstream ridges (Engelhardt and Kamb, 1993; Kamb, 2001). The premature, simulated switch from basal freezing to melting is mainly due to thickening of the ice column by $\sim 230 \mathrm{~m}$ during the last 15000 model years (Fig. $7 \mathrm{~d}$ ). This thickening event is due to an increase in accumulation rate of approximately $50 \%$ (Fig. 7b). Thickening promotes development of low basal temperature gradients on a long-term basis, but the pressure-melting point at the bed responds instantly to changes in the overburden pressure. Clearly, we know that the West Antarctic ice sheet has been thinning dramatically during the Holocene (Conway and others, 1999). In our opinion, this 
unsatisfactory performance of our model is caused by the fact that thickness of real interstream ridges is primarily driven by thinning/thickening of ice streams around them (Nereson and Raymond, 2001). Our treatment of ice dynamics is more suitable for a simple ice dome (Raymond, 1983) and does not include the necessary boundary forcing due to activity of nearby ice streams.

In spite of the limitations of our model, it clearly demonstrates that changes in the basal thermal regime produce significant changes throughout the basal zone. Figure $6 \mathrm{c}$ shows solute concentration at the ice-till interface during multiple melting/freezing events. Melting dilutes the pore water, while solute rejection during basal freeze-on increases the solute content at the ice-till interface. For interstream ridges, the isotopic composition of the basal ice and the underlying sediments reflects a low freeze rate $\left(<1 \mathrm{~mm} \mathrm{a}^{-1}\right)$. Such a profile (Fig. 6d) should be recognizable in basal ice cores and in subglacial till cores.

\section{GONGLUSIONS}

In a set of numerical simulations, we have explored changes in the basal zones of ice streams and interstream ridges. A new thermodynamic treatment of basal freeze-on based on concepts from frost-heave simulations provides the basis for simulating thermally induced pore-water flow in sub-icesheet environments. For ice streams, this subglacial water flow is capable of triggering ice-stream stoppage, due to consumption of free water present at the ice-till interface and subsequent withdrawal of pore water from underlying subglacial sediments. Till dewatering and consolidation is triggered by supercooling, which arises from surface tension effects that inhibit ice growth in pore spaces of fine-grained subglacial sediments. Supercooling should leave a distinct signature in the temperature profile of the overlying glacier ice. It should also be associated with reduced water pressures at the ice-till interface. Both effects may be measurable in subglacial boreholes. When release of latent heat becomes significant in the basal zone, thick layers of debris-laden basal ice may develop. Such layers have been observed in many of the deep ice cores drilled to the base of modern ice sheets. Freeze-on-driven extraction of subglacial pore water leads to lowered porosity values in the subglacial sediments. Beneath stopped ice streams, the porosity changes are most pronounced near the ice--till interface. However, thermally induced hydraulic gradients may reach depths of $50 \mathrm{~m}$ or more when climatically controlled freeze-on occurs over tens of thousands of years. Regional-scale pore-water gradients induced between areas of basal melting and regions of basal freezing may force deep subglacial ground-water flow. The basal meltwater produced beneath active ice streams may thus be driven towards the ice base of interstream ridges where basal freeze-on is ongoing.

\section{AGKNOWLEDGEMENTS}

Partial financial support for this research was provided by the U.S. National Science Foundation (grants NSF-OPP 9873593 and 0096302), Kaj og Hermilla Ostenfeld's Fond and Knud Højgaard's Fond.

\section{REFERENGES}

Alley, R. B. 1993. In search of ice-stream sticky spots. f. Glaciol., 39(133), $447-454$.

Alley, R. B. 2002. On thickening ice? Science, 295(5554), 451-452.

Alley, R. B., D. D. Blankenship, C. R. Bentley and S.T. Rooney. 1987. Till beneath Ice Stream B. 3. Till deformation: evidence and implications. 7. Geophys. Res., 92(B9), 8921-8929.

Alley, R. B., S. Anandakrishnan, C. R. Bentley and N. Lord. 1994. A waterpiracy hypothesis for the stagnation of Ice Stream C, Antarctica. Ann. Glaciol., 20, 187-194.

Alley, R. B., K. M. Cuffey, E. B. Evenson, J. C. Strasser, D. E. Lawson and G. J. Larson. 1997. How glaciers entrain and transport basal sediment: physical constraints. Quat. Sci. Rev., 16(9), 1017-1038.

Anandakrishnan, S. and R. B. Alley. 1997. Stagnation of Ice Stream C, West Antarctica by water piracy. Geophys. Res. Lett., 24(3), 265-268.

Anandakrishnan, S., D. D. Blankenship, R. B. Alley and P. L. Stoffa. 1998. Influence of subglacial geology on the position of a West Antarctic ice stream from seismic observations. Nature, 394(6688), 62-65.

Anandakrishnan, S., R. B. Alley, R.W. Jacobel and H. Conway. 2001. The flow regime of Ice Stream $\mathrm{C}$ and hypotheses concerning its recent stagnation. In Alley, R. B. and R. A. Bindschadler, eds. The West Antarctic ice sheet: behavior and environment. Washington, DC, American Geophysical Union, 283-294. (Antarctic Research Series 77.)

Anderson, J. B. 1999. Antartic marine geology. Cambridge, etc., Cambridge University Press.

Bell, R. E. and 6 others. 1998. Influence of subglacial geology on the onset of a West Antarctic ice stream from aerogeophysical observations. Nature, 394(6688), 58-62.

Bentley, C. R. 1987. Antarctic ice streams: a review. F. Geophys. Res., 92(B9), 8843-8858.

Bentley, C. R. 1998. Geophysics. Ice on the fast track. Nature, 394(6688), 21-22.

Bentley, C. R., N. Lord and C. Liu. 1998. Radar reflections reveal a wet bed beneath stagnant Ice Stream $\mathrm{C}$ and a frozen bed beneath ridge $\mathrm{BC}$, West Antarctica. 7. Glaciol., 44(146), 149-156.

Blankenship, D. D., C. R. Bentley, S. T. Rooney and R. B. Alley. 1986. Seismic measurements reveal a saturated porous layer beneath an active Antarctic ice stream. Nature, 322(6074), 54-57.

Blankenship, D. D., C. R. Bentley, S. T. Rooney and R. B. Alley. 1987. Till beneath Ice Stream B. 1. Properties derived from seismic travel times. 7. Geophys. Res., 92(B9), 8903-8911.

Bougamont, M., S. Tulaczyk and I. Joughin. 2002. Response of subglacial sediments to basal freeze-on: II. Application in numerical modeling of the recent stoppage of Ice Stream C, West Antarctica. 7. Geophys. Res., 107. (10.1019/2002JB001936.)

Boulton, G. S. and U. Spring. 1986. Isotopic fractionation at the base of polar and sub-polar glaciers. F. Glaciol., 32(112), 475-485.

Carsey, F., H. Engelhardt, A. Behar and A. L. Lane. 2001. Ice borehole video of basal domain of Ice Stream C in the 2000-2001 field season. [Abstract.] Eos, 82(47), Fall Meeting Supplement, F536.

Carsey, F., A. Behar, A.L. Lane and H. Engelhardt. In press. A borehole camera system for imaging the deep interior of ice sheets. F. Glaciol.

Christoffersen, P. and S. Tulaczyk. In press a. Response of subglacial sediments to basal freeze-on: I. Theory and comparison to observations from beneath the West Antarctic ice sheet. 7. Geophys. Res.

Christoffersen, P. and S. Tulaczyk. In press b. Signature of palaeo-ice stream stagnation: till consolidation induced by basal freeze-on. Boreas.

Conway, H., B. L. Hall, G. H. Denton, A. M. Gades and E. D. Waddington. 1999. Past and future grounding-line retreat of the West Antarctic ice sheet. Science, 286(5438), 280-283.

Domenico, P. A. and F.W. Schwartz. 1990. Physical and chemical hydrogeology. Chichester, John Wiley and Sons.

Engelhardt, H. 2001. West Antarctic ice stream dynamics. [Abstract.] Eos, 82(47), Fall Meeting Supplement, F536.

Engelhardt, H. and B. Kamb. 1993. Vertical temperature profile of Ice Stream B. Antarct. 7. U.S., 28(5), Review 1993, 63-66.

Engelhardt, H. and B. Kamb. 1997. Basal hydraulic system of a West Antarctic ice stream: constraints from borehole observations. F. Glaciol., 43(144), 207-230.

Engelhardt, H. and B. Kamb. 1998. Basal sliding of Ice Stream B, West Antarctica. f. Glaciol., 44(147), 223-230.

Engelhardt, H., N. Humphrey, B. Kamb and M. Fahnestock. 1990. Physical conditions at the base of a fast moving Antarctic ice stream. Science, 248(4951), 57-59.

Fowler, A. C. and W. B. Krantz. 1994. A generalized secondary frost heave model. SIAM J. Appl. Math., 54(6), 1650-1675.

Gades, A. M., C. F. Raymond, H. Conway and R.W. Jacobel. 2000. Bed properties of Siple Dome and adjacent ice streams, West Antarctica, inferred from radio-echo sounding measurements. F. Glaciol., 46(152), 88-94. 
Hamilton, G. S. 2002. Mass balance and accumulation rate across Siple Dome, West Antarctica. Ann. Glaciol., 35, 102-106.

Hindmarsh, R. C. A. 1999. Pore-water signal of marine ice-sheets. Global Planet. Change, 23(1-4), 197-211.

Hohmann, M. 1997. Soil freezing - the concept of soil water potential. State of the art. Cold Reg. Sci. Technol., 25(2), 101-110.

Hooke, R. LeB. 1998. Principles of glacier mechanics. Upper Saddle River, NJ, Prentice Hall.

Hopke, S.W. 1980. A model for frost heave including overburden. Cold Reg. Sci. Technol., 3(2-3), 111-127.

Joughin, I. and S. Tulaczyk. 2002. Positive mass balance of the Ross Ice Streams, West Antarctica. Science, 295(5554), 476-480.

Kamb, B. 1991. Rheological nonlinearity and flow instability in the deforming bed mechanism of ice stream motion. 7. Geophys. Res., 96(B10), $16,585-16,595$

Kamb, B. 2001. Basal zone of the West Antarctic ice streams and its role in lubrication of their rapid motion. In Alley, R. B. and R. A. Bindschadler, eds. The West Antarctic ice sheet: behavior and environment. Washington, DC, American Geophysical Union, 157-199. (Antarctic Research Series 77.)

Konrad, J.-M. and C. Duquennoi. 1993. A model for water transport and ice lensing in freezing soils. Water Resour. Res., 29(9), 3109-3124.

Mitchell, J. K. 1993. Fundamentals of soil behaviour. Second edition. New York, John Wiley and Sons Inc.

Miyata, Y. 1998. A thermodynamic study of liquid transportation in freezing porous media. FSME Int. F., Ser. B. Fluids Therm. Eng., 41(3), 601-609.

Nakano, Y. 1999. Water expulsion during soil freezing described by a mathematical model called M-1. Cold Reg. Sci. Technol., 29(1), 9-30.

Nereson, N. A. and C. F. Raymond. 2001. The elevation history of ice streams and the spatial accumulation pattern along the Siple Coast of West Antarctica inferred from ground-based radar data from three inter-ice-stream ridges. F. Glaciol., 47(157), 303-313.

O'Neill, K. and R. D. Miller. 1985. Exploration of a rigid ice model of frost heave. Water Resour. Res., 21 (3), 281-296.

Padilla, F. and J.-P. Villeneuve. 1992. Modeling and experimental studies of frost heave including solute effects. Cold Reg. Sci. Technol., 20(2), 183-194.

Paterson, W. S. B. 1994. The physics of glaciers. Third edition. Oxford, etc., Elsevier.

Petit, J.-R. and 18 others. 1999. Climate and atmospheric history of the past 420,000 years from the Vostok ice core, Antarctica. Nature, 399(6735), 429-436.

Price, S. F. and I. M. Whillans. 2001. Crevasse patterns at the onset to Ice Stream B, West Antarctica. 7. Glaciol., 47(156), 29-36.

Raymond, C. F. 1983. Deformation in the vicinity of ice divides. F. Glaciol., 29(103), 357-373.

Raymond, C. 1996. Shear margins in glaciers and ice sheets. F. Glaciol., 42(140), 90-102.
Raymond, C. F., K. A. Echelmeyer, I. M. Whillans and C. S. M. Doake. 2001. Ice stream shear margins. In Alley, R. B. and R. A. Bindschadler, eds. The West Antarctic ice sheet: behavior and environment. Washington, DC, American Geophysical Union, 137-155. (Antarctic Research Series 77.)

Rooney, S. T., D. D. Blankenship, R. B. Alley and C. R. Bentley. 1991. Seismic reflection profiling of a sediment-filled graben beneath Ice Stream B, West Antarctica. In Thomson, M. R. A., J. A. Crame and J.W. Thomson, eds Geological evolution of Antarctica. Cambridge, Cambridge University Press, 261-265.

Souchez, R. A. and R. D. Lorrain. 1991. Ice composition and glacier dynamics. New York, etc., Springer-Verlag. (Springer Series in Physical Environment 8.

Souchez, R., J.-L. Tison and J. Jouzel. 1987. Freezing rate determination by the isotopic composition of the ice. Geophys. Res. Lett., 14(6), 599-602.

Studinger, M., R. E. Bell, D. D. Blankenship, C. A. Finn, R. A. Arko and D. L. Morse. 2001. Subglacial sediments: a regional geological template for ice flow in West Antarctica. Geophys. Res. Lett., 28(18), 3493-3496.

Tester, R. E. and P. N. Gaskin. 1996. Effect of fines content on frost heave. Can. Geotech. F., 33(4), 678-680.

Tulaczyk, S. 1999. Ice sliding over weak, fine-grained tills: dependence of ice-till interactions on till granulometry. In Mickelson, D. M. andJ.W. Attig, eds. Glacial processes: past and present. Boulder, CO, Geological Society of America, 159-177. (Special Paper 337.)

Tulaczyk, S., B. Kamb, R. P. Scherer and H. F. Engelhardt. 1998. Sedimentary processes at the base of the West Antarctic ice stream: constraints from textural and compositional properties of subglacial debris. F. Sediment Res., 68(3A), 487-496.

Tulaczyk, S. M., B. Kamb and H. F. Engelhardt. 2000a. Basal mechanics of Ice Stream B, West Antarctica. I. Till mechanics. 7. Geophys. Res., 105(B1), 463-481.

Tulaczyk, S. M., B. Kamb and H. F. Engelhardt. 2000b. Basal mechanics of Ice Stream B, West Antarctica. II. Undrained-plastic-bed model. $\mathcal{F}$ Geophys. Res., 105(B1), 483-494.

Tulaczyk, S., B. Kamb and H. F. Engelhardt. 2001a. Estimates of effective stress beneath a modern West Antarctic ice stream from till preconsolidation and void ratio. Boreas, $\mathbf{3 0}(2), 101-114$.

Tulaczyk, S. M., R. P. Scherer and C. D. Clark. 2001b. A ploughing model for the origin of weak tills beneath ice streams: a qualitative treatment. Quat. Int., 86(1), 59-70.

Van der Veen, C. J. 1999. Fundamentals of glacier dynamics. Rotterdam, etc. A. A. Balkema Publishers.

Whillans, I. M., C. R. Bentley and C. J. van der Veen. 2001. Ice Streams B and C. In Alley, R. B. and R. A. Bindschadler, eds. The West Antarctic ice sheet: behavior and environment. Washington, DC, American Geophysical Union, 257-281. (Antarctic Research Series 77.) 